Research Article

\title{
The Management Implementation of Character Value at Junior High School
}

\author{
Sisilia Sipiana *, Ahmad Suriansyah, Rustam Effendi \\ Master Program of Education Management, Universitas Lambung Mangkurat, Banjarmasin, Indonesia \\ 70123
}

Article history:

Submission November 2019

Revised February 2020

Accepted May 2020

${ }^{*}$ Corresponding author:

E-mail: ninohubertine@yahoo.com

\begin{abstract}
This study aims to plan and evaluate the implementation of character values. It was carried out in Santa Angela Banjarmasin and Sanjaya Banjarbaru Junior High Schools using the qualitative, empirical, and multi-site design approaches. Furthermore, the research subjects comprise of principal, viceprincipals, teachers, students, committees, and the school Foundation. Data were collected through observation, in-depth interviews, and documentation. Analysis of the data collected was conducted through reduction, conclusion, presentation, and verification. The results of the study, therefore, aimed at the implementation of character values to students through planning, organizing, implementing, and evaluating. These stages are appropriately carried out in school management, implemented in its curriculum, with results developed into character values.
\end{abstract}

Keywords: Management, implementation, character value

\section{Introduction}

The education standard of Indonesia schools is complex, with of character value poorly taught, thereby, leading to the spread of moral decadence. Therefore, there is an adequate need for the promotion and implementation of character values in schools (Mulyasa, 2007).

According to Lickona (2010), ten factors need to be managed to have a proper education system and structures. These ten effects are as follows: 1) violence and vandalism. 2) theft committed by students 3) plagiarism or dishonesty, 4) lack of respect for parents and elders, 5) violence caused by peer pressure, 6) prejudice, intolerance, and hostility to people from different beliefs, 7) moral decay, 8) freedom of sexuality and hatred, 9) being irresponsible, and 10) Alcoholism and drug abuse.

The above problems are catalyzed by the advancement of the cyber world which is trends in automation in exchanging data via the internet for all human thought capacities and thinking abilities. In the era of the industrial revolution, 4.0 called the digital era became the main challenge for the government in improving its generation. Through the character, education will greatly influence the behavior of the community so that it is carried out directed by the state.

According to Lickona et al., (2007) an effective character education must include an effort to assess progress. Three broad kinds of outcomes merit attention are: (1) the character of the school: students indicate to an extent with the statement "this school is like family"; (2) the school staff's growth as character education: staff, administrator and support personnel understanding to do foster, commitment character development and developing capacities as character education; (3) student character; the school can gather data on various character-related behaviors. Schools can also assess the three-domain of character (knowing, feeling, and behaving),

How to cite:

Sipiana, S., Suriansyah, A., \& Effendi, R. (2019). The management implementation of character value at junior high school. Journal of K6, Education, and Management, 2 (3), 204 - 210. doi: 10.11594/jk6em.02.03.04 
student moral judgment, moral commitment, self-reported moral behavior.

School as an educational institution that seeks improvement for a better future needs an educational pattern that can answer the challenges of the times. According to Islam (2017), character education is a conscious effort that is planned and directed through a learning environment for the development of human potential that has good character and personality, morals, and positive constructive effects on nature and society.

It can be concluded that the implementation of character education that applied to educational institutions can help the child personally to live and actualize himself in the family, community, and country.

According to the Ministry of National Education, (2010), students are encouraged to have national values and embrace cultural education since they inculcate a sense of nationalist and productivity as responsible members of the society. Koesoema (2012) argues that education is a social process that aims to equip students with skills and norms valued by society. These aid them in being responsible and professional etiquette.

The development of education programs and character needs to be adequately monitored, with student's evaluation carried out coupled accompanied by continuous observations. According to Zuchdi (2008) schools need to teach values in their programs. Therefore, learning character values is not only at the cognitive level but on the internalization and real practice in the lives of students and society.

There are four types of character education in schools that enhance students' character and personality. These include: 1) Manifestation of character education by making new subjects, 2) Its integration into the curriculum, 3) its inclusion as a subject, 4) Character education through informal curriculum approach (Koesoema, 2012).

Regarding the discussion of characters, proverbs (including Banjar proverbs) are the most effective and most often used as enhancement character values. Viewed from the side of the form, Banjar proverb can be divided into two types namely the type that describes or displays human beings with ideal character (positive character) and shows humans who are characterless or ignore character. Although the two types seem to be at odds to achieve ideal character values to members of the community (Effendi, 2014).

Suryadi (2010) states six basic elements determine the success of the development of character education in schools, namely (1) the effective leadership of the school principal as a pioneer in character education in schools; (2) schools that are disciplined as a moral institution; (3) the growth of a harmonious sense of family at school; (4) the growth of a democratic climate in school; (5) the creation of a close collaboration between the school community as a moral and intellectual force for the growth of positive character; and (6) schools need to provide a special time to deal with moral issues at school.

The success of character education requires the role of the principal in developing strategies for implementing character education in schools. According to Suriansyah (2015), to shape students' character, the school principal needs to an incorporated strategy with the value of philosophical leadership, examples, discipline, instructional leadership, quality leadership, and empowering teachers and education personnel. In another hand, the teacher's strategy is exemplary, habituation, and heart touch. The parents and community strategy is effective communication and effective partnership. Character education implemented in schools is inseparable from the identification, analysis, and mapping of the objectives of character education in schools. Bahrun (2016) stated in his research in three schools in Aceh Province that in the development of character education in schools there needs to be a comprehensive policy to strengthen teacher competence. As a shortterm solution, conventional options such as training, outreach, and mentoring are needed. The medium-term solution, the policy option is focused on strengthening K13 assistance in schools. The long-term solution to the introduction of school development policies lies in the standing position.

The implementation of character-based education through the honesty canteen in 
schools still varies depending on the layout and type of each school, including how the role of the school in instilling character values (Salabi, 2014).

Based on the background of the problem, the objectives in this study are the implementation of character value management in junior high school including (1) character value planning; (2) organizing character values (3) implementing character values and (4) evaluating character values.

\section{Material and Methods}

This research approach is a qualitative technique with multi-site study design. The study location was at Santa Angela Banjarmasin and Sanjaya Banjarbaru Junior High School. Research objects include time, place, social and cultural settings. The research subjects were the principal, vice-principal, administration staff, school committee, students, and supervisors.

The technique of data verification using triangulation including: (1) observation; (2) interview; and (3) documentation. Data collected through various techniques are examined and data reduction, data presentation, and data verification are carried out. Checking the validity of the data is done using credibility, transferability, dependability, and confirmability. Then the data are analyzed with a single analysis and cross-site analysis.

A purposive technique aims to conduct the determination of research subjects by selecting some informants tailored to the objectives. Data was collected through in-depth interviews, observation, and documentation (Sugiyono, 2008). The primary data was obtained from in-depth interviews with key informants from school principals, viceprincipals, teachers, students, committees, and foundations. Furthermore, the triangulation and inductive techniques were used to reduce, analyze, validate, conclude, verify, and present the data.

\section{Results and Discussion}

The results of the study show that management implemented character values in schools through planning, organizing, implementation, and evaluation. These values enable students to act professionally and develop ethical characters. The goal is to integrate character value training into the schools' curriculum.

\section{Finding at Banjarmasin Santa Angela Junior High School}

Following the findings at Banjarmasin Santa Angela Junior High School, the following need to be implemented:

Planning tailored to meet the needs of students at the beginning of each school year needs to be conducted as it helps to form students' character in the exemplary habituation. This result according to Kamaruddin's (2012) research to desire to build the character of students, has poured into the strategic planning program design in a systematic and integrated. Program character education alters the character of the student gives a positive color in an atmosphere of learning. Another research by Brown (2005) character education is such curricula. There are many and various programs which are called character education and the system delivery varies by location. Character and character education in Washington DC have been a concern for many years. The demand for effective programs mirrors the demand for safe school.

Organized character education at Santa Angela Junior High School is the principal needs to provide clear job descriptions in the curriculum development team. This research is in collaboration with the development team, helping the principal in implementing character education at school.

This acts similarly to the resulting research by Nez (2014) who researched SMA Negeri 4 Kota Tegal. The organizing activities were carried out by the principal through several stages, namely arranging the organizational structure, compiling the main tasks of the teacher, compiling additional tasks forming a technical team implementing character education. Another research by Yusoff and Hamzah (2015) in Malaysia about develop concept focus to character development with the integration of seven (7) components are (1) ethics and moral; (2) leadership; (3) 
communication; (4) entrepreneurship; (5) thinking skills; (6) continuous learning and information management; and (7) teamwork. Character development is accomplished utilizing the global thinking approach following Malaysia's identity.

Actuating at Santa Angel Junior High School in Character education programs should be adequately implemented by collaborating and fostering harmonious relations with all school residents and parents of students. Furthermore, understanding the background of students helps to implement the best character values in the learning process. These results are in line with the opinion of Bahri (2015) that in the implementation of character education integration in schools is carried out in three areas, namely through learning, selfdevelopment, and extracurricular and school culture. Effective school culture through school principals, teacher and staff administration, collaboration with the community through soft value builds synergy of cooperation with parents, stakeholders in the community and school board of education councils in facing global challenges.

Actuating of character education in line with the study by Dalimunthe (2015) the implementation of character education strategy in SMP Negeri 9 Yogyakarta through integrating values and ethic in school subjects, the internalization of positive values instilled by all of the creation of an atmosphere of a school with character in and habit formation. The implementation of character education was done through the integrated news of character formation with teaching and learning, school management, and extracurricular activities.

The result of research about the implementation of character education in Turkey by Pala (2011) about the development of socialization skills and integration of character education is an important part of a child's academic success. Character education efforts may be effective when implementation through some activities to develop character, classroom strategies, and participants in character education such as parents, schools, and teachers. Supervision and Evaluation in Santa Angela Junior High School need to be conducted yearly and monthly, to get acquainted with the parents of students. This helps to discuss the development of children at school with follow up at home. In line with the study of Darmayanti and Wibowo (2014) who researched the Kulon Progo Regency with the result that the evaluation activities were carried out by the Kulon Progo District Education Office in administrative (curriculum) and monitoring activities carried out by school supervisors in each district. In line with the results of research by Mislia et al., (2016) through headmaster's role and duties to develop character values uses evaluation and monitoring conducted at the beginning of the character education program.

Evaluation of character education has done before by Harington et al., (2001) in North Carolina, the title of the research is the evaluation of the All-Stars Character Education and Problem Behavior Prevention Program. The sample they research is African, American, White, and Hispanic students at middle school (11-13 years). Target's effect on mediators is bonding, commitment, ideals, and norm. the result of targeted mediator summary analyses suggests that the All-Stars Program when administered by the teacher, had an immediate positive effect on commitment and ideals. The inclusion of ethnicity in the design suggested that the program seemed to have a consistent, positive effect on the mediating variable for African American Student. The outcome variables are sexual activity, substance (drug)use, and violence increased throughout the study but most markedly between the posttest and follow-up assessments. Research by Narvaez et al., (2004) in Minnesota, samples of these researches are staff and students at five schools who participated in an evaluation of the model over 1 year using Minnesota's Community Voices and Character Education Project. The result that attempted to integrate a classical view of what character is with current psychological literature. Character is viewed as a set of teachable skills in ethical sensitivity, judgment, focus, and action. These skills can be embedded across a standarddriven academic curriculum and be cultivated by teachers using best practices for cultivating expertise. 
Another research about monitoring and evaluation models for character education in school by Sumardiyani et al., (2017) as follows: (1) the model was developed by looking at the four components: self-awareness, social awareness, and self-management character.

\section{Finding at Sanjaya Banjarbaru Junior High School}

Efforts to realize character education management in Banjarmasin Santa Angela and Sanjaya Banjarbaru Junior High Schools are not optimally achieved. Therefore, adequate planning, organizing, implementation, and evaluation need to be conducted by all school members. However, society, family, and school play a role in character education, which centers on the development of a child. Parents have a primary role to play in the development of their children while the teachers help in educating and nurturing them in schools.

Following the findings at Sanjaya Banjarbaru Junior High School, the following need to be implemented are:

Planning uses Yearly planning should be conducted by forming a team and planning a character education program in exemplary habituation to increase quality and character graduates. Research conducted by Rozaq (2015) which found character education planning activities in Sendang State Elementary School is to compile learning tools in which there are character values that are appropriate to the needs of students. Character values that will be achieved are honesty, cooperation, and discipline. The implementation of character education is following the opinion of Koesoema (2012) is a core activity carried out in schools. It is conducted in four stages, namely; (a) formulation through subjects, (b) daily activities, (c) implementation into planned/programmed activities, (d) establishing communication between schools and parents.

Regarding character-based learning, planning explained by Nadzir (2013) that planning is a set of materials and tools prepared by the teacher. Planning model that emphasizes aspects of planting moralcharacter values for students.

Organizing character education uses the school principal needs to organize a curriculum development team to carry out the design and development of character values in the curriculum. In line with the findings of research by Maisaro et al., (2018) that the program of character education strengthening is coordinated by the principal to make the development team as the main coordinator. The management of the character education strengthening program are: (1) the school principal responsible for school activities and policies; (2) the school development team, which is a coordinator and school quality developers in assisting the school principal in supervising and making program activities; and (3) the school coordinator who helps the school development team.

The implementation of character education that uses exemplary habituation which integrates activities in daily life. This leads to students possessing skills comparable with graduates from other schools. Cultivating student character through habituation, in line with research conducted by Batubara (2015), that honest character development strategies through habituation (conditioning). The basic principle that developing an honest character is obtained through the habituation of learning. The principle of habituation is needed in the learning process, especially in the formation of behavior. Individuals will still do good if they get a positive response from their environment (the presence of stimulus-response and reinforcement). According to Salasiah et al., (2018) implementation strategies that are used in PAUD Islam Sabilal Muhtadin dan PAUD Mawaddah through habituation, exemplary, assignment, direction, and conditioning (cultural).

About monitoring and evaluation in Sanjaya Junior High School are conduct internal and external supervisory control management through discipline and home visits, respectively. Results of quasi-experimental research by Top et al., (2017) in which 22 largest schools in Texas. This research including the cross-level interaction effect 
between the second step curriculum and parental monitoring on school outcomes and the use of an in-class behavior observation system by the teacher. The results show that parental monitoring had effects on schooling outcomes during middle childhood and adolescence.

Supervision and evaluation activities through family and community involvement following the Mandate of Law Number 20 of 2003 concerning the national education system in article 8 that the community has the right to participate in planning, implementing, monitoring, and evaluating educational programs. In article 56 paragraph 3 that the school committee is formed and plays a role in improving the quality of education services at the level of the education unit (Kementrian Pendidikan dan Kebudayaan, 2017)

The character values evaluation needs to be conducted by parents and school staff as character educators. Assessment should also be carried out on students to gauge the manifestation of good character.

\section{Conclusion and Recommendation}

Planning the implementation of character values in SMP Santa Angela Banjarmasin and Sanjaya Banjarbaru Junior High School needs to be carried out by holding meetings to plan the establishment, as well as the formulation of vision, mission, and school goals through needs analysis. Context analysis conducted involved all school members and stakeholders in the world of education, with implementation plans put in place. While character values in Santa Angela Banjarmasin and Sanjaya Banjarbaru Junior High need to be conducted through a clear division of tasks accompanied by assignments and guidelines from the school principal. Implementation of character was carried out under the programs which occurred inside and outside the class habituation and extracurricular activities. The evaluation was conducted annually and per semester to determine how character values are lived and how its implementation is carried out in schools. Through evaluation, subsequent characters are developed with a habit for all students.

Based on the research conducted, schools were advised to adhere to the following: (1)
Consistently carry out character value education in academic and non-academic fields; (2) Improve the quality and program needs of character values based on systematic and role models. There needs to the integration of activities and programs through school and home visits; (3) The school needs to improve character management in education and strengthen its policies in the form of a character-based curriculum. Furthermore, discipline should be enhanced in schools to teach noble characters and make students contribute positively to the society, nation, and state.

\section{Acknowledgment}

The author is grateful to the Postgraduate Master Program in Educational Management, Universitas Lambung Mangkurat Banjarmasin, for facilitating this research. Thanks for Santa Angela and Sanjaya Junior High School for supporting this project.

\section{References}

Bahri, S. (2015). Implementasi pendidikan karakter dalam mengatasi krisis moral di sekolah. Jurnal Ta'allum,3 (1), 57-77.

Bahrun. (2016). Kajian praktik-praktik terbaik pengembangan pendidikan karakter di sekolah dalam rangka implementasi kurikulum 2013. Jurnal Suloh: Bimbingan dan Konseling FKIP Unsyiah, 1(1), 64-74.

Batubara, J. (2015). Pengembangan karakter jujur melalui pembiasaan. Jurnal Konseling dan Pendidikan, 3(1), 1-6. doi:http://jurnal.konselingindonesia.com/index.php/jkp/ article/view/120.

Brown, J. (2005). Character education: A resurgence to safety, a perspective in curricula trend. Academic Leadership: The Online Journal, 3(1), 1-5.

Dalimunthe, R. A. (2015). Strategi dan implementasi pelaksanaan pendidikan karakter di SMP N 9 Yogyakarta. Jurnal Pendidikan Karakter, 1, 102-112. doi:10.21831/jpk.v0i1.8616.

Darmayanti, S. E., \& Wibowo, U. B. (2014). Evaluasi program pendidikan karakter di sekolah dasar Kabupaten Kulon Progo. Jurnal Prima Education, 2(2), 223-234. doi:10.21831/jpe.v2i2.2721

Effendi, R. (2014). Pribahsa Banjar (Menampilkan karakter negatif untuk pendidikan karakter positif). Jurnal kajian sastra, 3(2), 57-78. doi: 10.21274/taalum.2015.3.1.57-76

Harrington, N. G., Giles, S. M., Hoyle, R. H., Feeney, G. J., \& Yungbulth, S. C. (2001). Evaluation of the All-Stars 
character education and problem behavior prevention program: effects on mediator and outcome variabel for middle school students. Sage Journal: Health Education \& Behavior, 28(5), 533-546. doi:10.1177/109019810102800502.

Islam, S. (2017). Karakteristik pendidikan karakter: menjawab tantangan multidimensional melalui implementasi kurikulum 2013. Jurnal Pendidikan Islam Edureligia, 1(1), 89-101. doi:10.33650/edureligia.v1i2.50.

Kamaruddin, S. A. (2012). Character education and students social behavior. Journal of Education and Learning, 6(4), 223-230.

Kementrian Pendidikan dan Kebudayaan. (2017). Kebijakan teknik pelibatan keluarga dan masyarakat di satuan pendidikan (PAUD, SD, SMP, SMA/SMK, SLB, dan PNF). Semarang: Direktur Pembinaan Pendidikan Keluarga: Ditjen PAUD dan Dikmas.

Koesoema, D. (2010). Pendidikan karakter, strategi mendidik anak di zaman global. Jakarta: Grasindo.

Lickona, T., Schaps, E., \& Lewis, C. (2007). CEP's eleven principles of effective character education. Washington DC: Washington DC.

Maisaro, A., Wiyono, B. B., \& Arifin, I. (2018). Manajemen program penguatan pendidikan karakter di sekolah dasar. Jurnal Administrasi dan Manajemen Pendidikan, 1(3), 302-312.

Mislia, Mahmud, A., \& Manda, D. (2016). The implementation of character education through scout activities. International Education Studies, $\quad 9(6), \quad 130-138$ doi:10.5539/ies.v9n6p130.

Mulyasa, E. (2011). Manajemen pendidikan karakter. Jakarta: Bumi aksara.

Nadzir, M. (2013). Perencanaan pembelajaran berbasis karakter. Jurnal Pendidikan Agama Islam, 2(2), 339-352.

Narvaez, D., Bock, T., Endicott, L., \& Lies, J. (2004). Minnesota's Community Voices and Character education project. Journal of Research in Character Education, 2(2), 89-112. doi:10.1.1.416.132\&rep=rep1\&type=pdf.

Nez, A. L. (2014). Model implementasi pendidikan karakter berbasis kurikulum 2013 di SMA Negeri 4 Kota Tegal. jurnal Educational Management, 3(2), 80-86.
Pala, A. (2011). The need for character education. International Journal of Social Sciences and Humanity Studies, 3(2), 2332.

Rozaq, A. (2015). Pengelolaan proses pembelajaran pendidikan karakter di sekolah dasar. Indonesian Journal of Curriculum and Educational Technology Studies, 3(1), 41-48.

Salabi, A. (2014). Implementasi pendidikan berbasis karakter melalui program kantin kejujuran pada sekolah - sekolah di Provinsi Kalimantan Selatan. Jurnal Ilmiah Ilmu pendidikan dan kedakwaan, 6 (2), 1-20.

Salasiah, Asniwati, \& Effendi, R. (2018). Instilling character values in early childhood in the perspective of curriculum and parenting (multi-site stucy in PAUD Islam Sabilal Muhtadin and PAUD Mawaddah, Banjarmasin, Indonesia). European Journal of Education Studies, 5(7), 36-48. doi:10.5281/zenodo.1494201.

Sugiyono. (2008). Penelitian kuantitatif, kualitatif $d n R \& D$. Bandung: Alfabeta.

Sumardiyani, L., Reffiane, F., Ayu, N., \& Lestari, S. (2017). Model of monitoring and evaluation of character education at Universitas PGRI Malang. International Journal of Active Learning, 2(2), 112-119.

Suriansyah, A. (2015). Strategi Kepemimpinan Kepala Sekolah, guru, orang tua dan Masyarakat dalam membentuk karakter anak. Jurnal cakrawala pendidikan, XXXIV (2),234-247. doi: https://doi.org/10.21831/cp.v2i2.4828

Suryadi, A. (2010). Sebuah model pendidikan karakter dalam sistem persekolahan di Indonesia: dalam potret profesionalisme guru dalam membangun karakter bangsa: pengalaman Indonesia dan Malaysia. Bandung: UPI Press.

Top, N., Liew, J., \& Luo, W. (2017). Family and school influences on Youths' behavioral and academic outcomes: Cross-level interaction between parental monitoring and character development curriculum. The Journal of Genetic Psychology, 178(2), 108-118. doi:10.1080/00221325.2017.1279118

Yusoff, M. Z., \& Hamzah, A. (2015). Direction of moral education teacher to enrich character education. Jurnal Ilmiah: Peuradeun, 3(1), 119-131.

Zuchdi. (2008). Sstrategi Meningkatkan kemempuan membaca peningkatan koperhensip. Yogyakarta: UNY Press. 